He was ordered to suck ice, and to inhale, by means of Lerluc's tuhe. a powder consisting of equal parts of ancesthesin and orthoform. A week later the pain hat considerahly diminished, and several shallow lentionlar nlcers with white edges were seen on the infiltrated regions on the left half of the larynx.

Dr. Dundas Grant arled that the question was whether it was a ase of localised miliary tuberoulosis, or a herpetic andition on tope of a tuberculous infiltration. It was confined to ene half of the larrons, and when he saw the ase nine days ago there was allute inflammation, with appeatrances on the surface which resembled histers. The question wats whether they were herpetic. If they were sis they might shrivel up. He would report on the cas later.

\title{
PROCEEDINGS OF THE SOCIETY OF GERMAN LARYNGOLOGISTS.
}

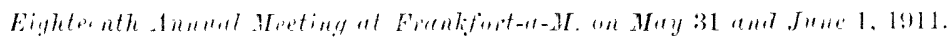

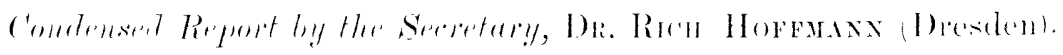
President-. Prot. Kundux Berlin).

$Y_{1+y}:: 1$.

Demonstration of a Series of Stereoscopic Photographs. heatring upen the Development of the Nuse and Nase-pharyngeal Tonsil

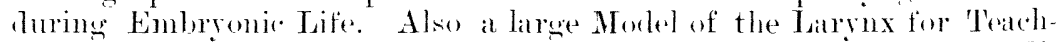
ing Purposes, with Mirror: Prepauations in Wax of Interesting Comalifions; Coloured D)iapositive: New Examination Lamp: Specollum for Dilating the Hyopharyx : and an Instrument for taking Measurement: in the Trarhea and Bromehi--Killian (Berlin).

Jutle 1.

Research bearing upon Important Questions in the Domain of Tuberculosis.--E. Rumpf (Ehersteinhurg).- - In his intreiluctor! remarks Rump faid stress on the fregueney of early laryoneal tuberculosis among patients in sanatoria, and the fatomalle influener on such cases of complete silenere, rest. and general toni" treatment. Doreover. he had often ohserved a much more marked and rapid impororement of the lung contition after the establishment of free nasal breathing.

Rumpt then referred to the work of Romer, of Marburg, who assumes that when once a tubereulous infection has oceured, a protection is conferred anginst a new tuberenkms infertion. 'This has heen shown experimentally by the results of serombary infection in apes and other animals, and is further suggested he the extraordinary frepuency of tuberculous infection in man, and especially by the fact that amone the civilised rares almost every indivilual after childhood must be regarded as infected.

In favour of the view that the tuberculous individual enjoys 


\section{April, 1912.] Rhinology, and Otology.}

immunity against further tuberculous infection, Röner puts forward many plausible argments apart from the analogy with the results of experiments on animals. A fresh tuberculous infection is not andureer in sanatoria and consumption hospitats, nor hy tuberculous chilitren fom their elder hrothers or sisters who are severely infected, nor in the matried state, nor in ocrupations which entail esplectal exposure to tulereulous infection: relative infrequency of a secomlary laryngeal am intestinal tubereulosis in comparison with the ereat oppertunity for inferten: harmlessness of subcutanenus infections with virulent tuberele. hallilli on tuberculous (because adhilt) patients (Batumgarten and Klemperer) : immunity of persons with pulmonary tubereulosis ayatinst the use of tuberenlous cow mille (as established by the Bond of Public Health); frequeney of the presemes of tulerere lateille in

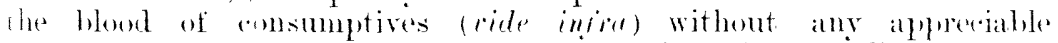
afferet. The immunity of man ateanst resinfection is, like all immunity, relative: too serere a re-infertion learls to pulmomary con-mmption. Re-intertions which leat to phthisis arise, not from without $(a . s)$, hut frem within. 'Ilse possilility of the accurrence of such serere re-infections depends upon the sererity of the inferetion which terk plater in childhoud. For, as a matter of experience it is just those persoms who an doubt as children, esperdally in the family. Were exponsed to severes thberculous infection, that temd to contratet phthisis (such cases heing inmerly wrongly regarided as herentiary). Prophrlaxis of (onsmuption must, therefore, allowe all aim at the perevention of severe infertions in hilithood.

Rumpt then proceeds to deal with the reports of the discoussoms of the International Thuberoulsis Comoresses so far as they are concerned with the question of the points of entrane of the infection and the spreat of mbercle barilli in the human berly. While formerly the great majority

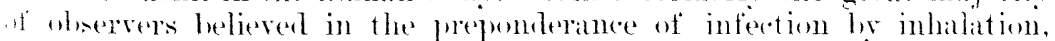
if munt be admitted after the discussions at the Hague and in Viema

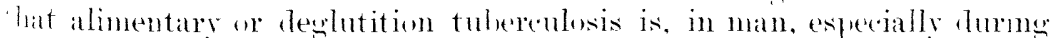
hililloorl, by far more frequent.

A temleney to sive up the inbalation hypothesis is moticeable inasimmeh as more observers declare themselves in farour of the view of the

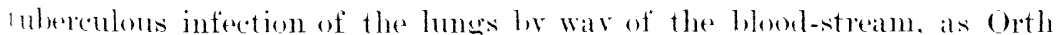
ibl twenty vears ago, and as now do bibbert and others still more

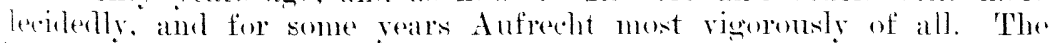

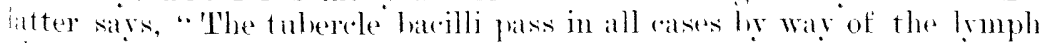

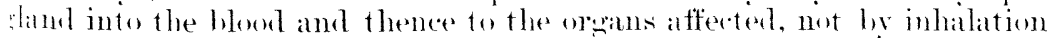
anto the lungs. The lumes are infeeted only from the cervieal and bron-

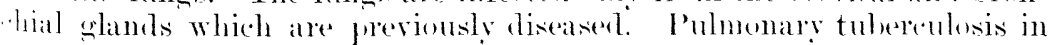
than originates only from the diseased walls of the smallest versels: the

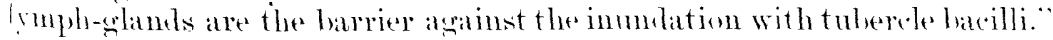

Rumpt himself, in Viemna, drew attention to the fact that a remark. hlle number of observers, while in other respects of willely different views. all agree as to the importance of the pharyo and experially of the pharyugeal tonsil as a point of entrance of infertion. He recalls the work of Hugo Bectimanm, who resarded as of primary impertance in "ombating tuherenlosis the closure of this main entrance-way of infeetion ly the completest possible removal of the pharyngeal tomsil, and, if reguired, treatment of the nose, the palatal tonsils, and the cervical saluds. Of recent experimental work Rumpe mentions that of Batumeister. which was intenden to throw light upon the tendency to infection of the apices. Baumeister fixed a loose wire noose round the first pair of 
ribs of young growing rabits. When the animals were then infecten. with tubercle hacilli. there developed immediately an isolater apicat tulerenlosis as the growing lumgs berame engaged in the too narros

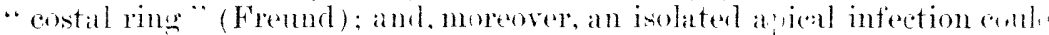
never bes perdured through the air-way. hut only by way of the blome stream (intertion from an inguinal olamt).

Rimupe then draws attention to the amalong with fuberenlesis of the

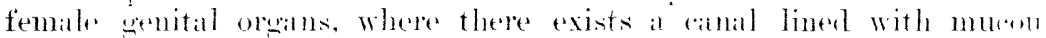
membrame having at wile communication with the exterior and therefine exposent to infertion by this path. Jung. howerese at the last Gynede

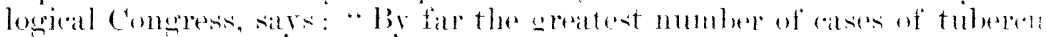
losis of the female wental organs origuate ly secombary intertion from the hisul-stream."

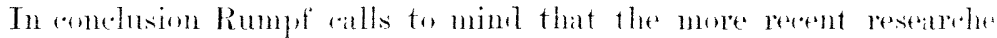

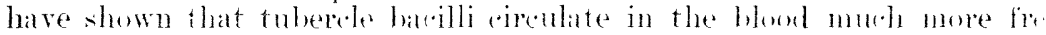

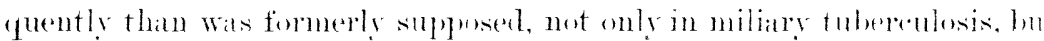

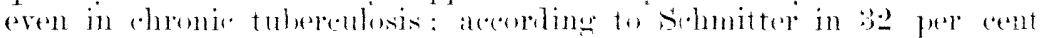

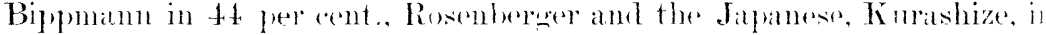
100 perer ant.

The latter examined the carefully centrifugalised heorde treated wit!

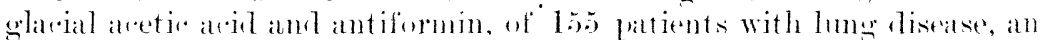

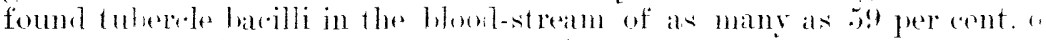

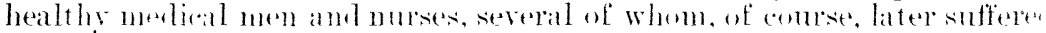
from piteurisy or hat an intial hemoptysis. In several instanes he wat

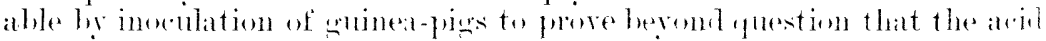

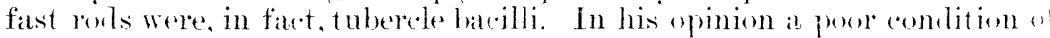
health and a lowering of the resistance, ats well ats the deeprese of vitalit:

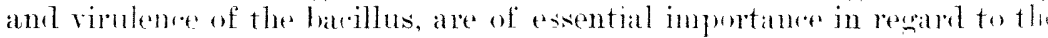
outhreak of a lisseminatel tubereulusis. Fren in the vere earliest stage of toberenlesis there is an apparenty continumes circulation of tuberet.

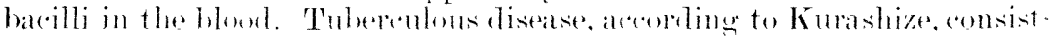

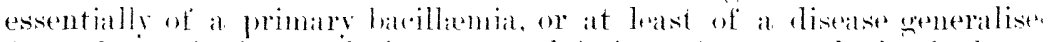

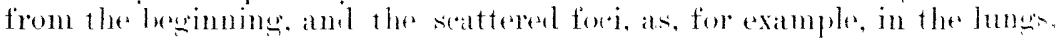

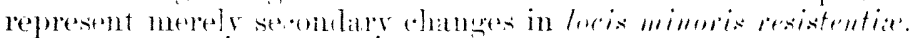

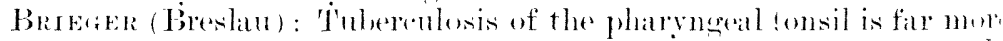

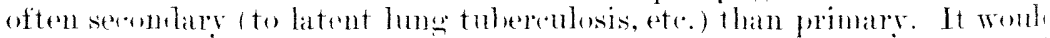

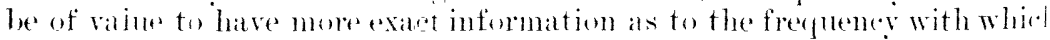
sanaterium treatment alons exerts a faventable influmese on laryngeral tuberculesis.

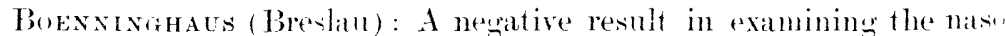
pharringeal tonsil for tuberoulosis is no proof that it hats not been the channel of infertion. The hacillus need leave no tratere of disease at it plawe of entry.

Roup (in reply) atid that the view just expresserl was constantl. gaining witer ace pitance. Thuberolesis of the pharrngeal tonsil ad certainly also arise seromlarily be way of the bleorl-stream. Spontanemhealneg of laryngeal tuhereulosis in samatoria is well establisherl. amm the

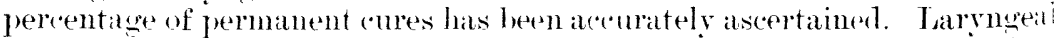
tulerenlowis is given in the institutions the nost thorough attention (Dissent.) It is, howerer, the fact that larrmageal tuberculosis is usull? secomlary to pulmonary disease.

Analysis of Artificial Yowel Sounds.-Gutzmann (Berlin).The artificial rowels are produced by convering into the mouth the sound of a membrinoms reed-pipe. When the cavity of the mouth i- 
Giales as during the natural production of the rowel, the artificial vowels ...nnd is olitained in a clear and very characteristic mamer. The speaker hall mule plontographic reeorls of a number of these artificial vowel ...mmb. and hat systematically analysed the tone-photongaphs thas

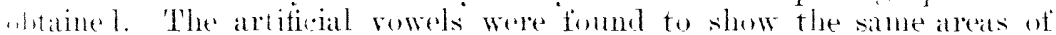
Hementation as the natural. Fisperially interesting is it to comprate the malysin of the simple pipe somel with that of the artiticial rowels. By ais means it is pessible to alprenciate at one the signitiontion of the

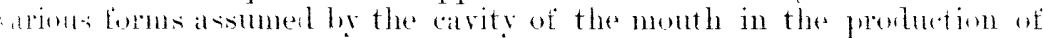

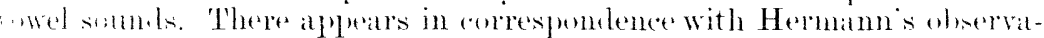
ans a definitely charateristir aumentation areat, while the strongly

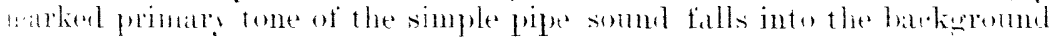

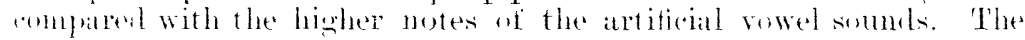

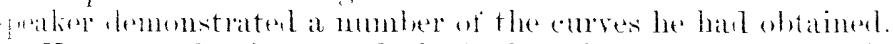

Fonsex (Frankfort) asked whether the tomes protuet in the naso.

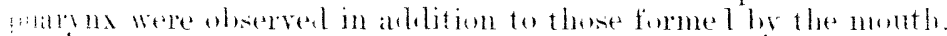

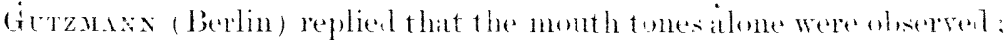
"forming the rowel " a " the solt palate was raised, and in forming " o" .mil " 11 " the nasophatrons wats completely shut oft.

The Diagnosis and Treatment of Functional Disorders of the yoice.-Gutzmann (Berlin).- The spealeer lemenstrat il some instru-

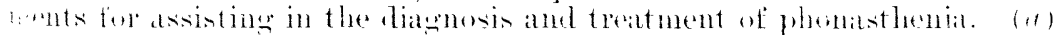

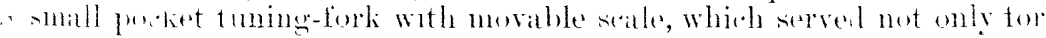

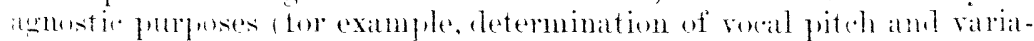

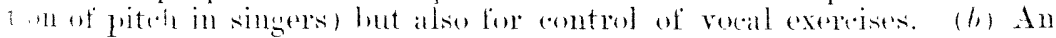

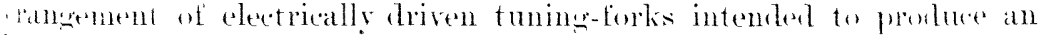
indritiation and vilmation of the latronx srnehromons with the pith of the furkenplenged.

The Exactitude of the Reproduction of Tones by Professional singers, - Lokolewsky (Königsherw).--Systematic olservations with

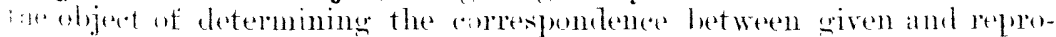

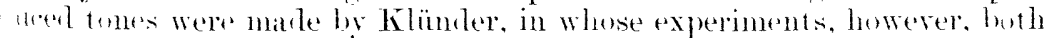
nes were in all eatses proheded sym-hromously. There were wanting.

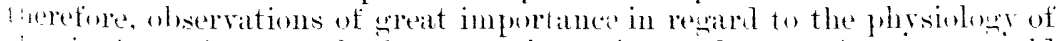

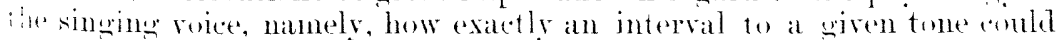
in sung and how exactly at giren tone could be struck after it had ceased fo somel. The following experiments are intemedel to fill these walps:

The alpatratus emplosed by the author for registering the tome viluat Sans consists of a combination of Einthoven ss string walvanometer amd

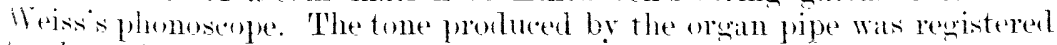
iy the string galvinometer and the reprofluced tone he the phomosente.

The experiments were carries out on four lanlies and three men nelonging to the opera. The first two series of olservations -(1) repro-

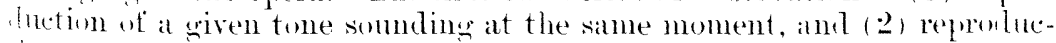

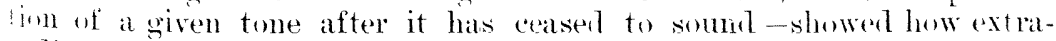
whinarily exactly the human larynx atn strike the true pitch. 'The lest "xsult attained showed an error of only or pere cent. 'Lhe third seriesinging of intervals to a given tone sounding at the same moment - gave a urprisingly different result from these of the first two series. The errors were considerably greater (as much as 4.54 and 551 per cent.). It was -triking that the fitth was sung with the least truth.

The anthor explainet the great inexactitule in singing the intervals by 
the fact that the errors, inseparable from the difficulty of singing quit. true intervals, become combined with those which the singer is accus tomed to make through his halit of practising with softened piano Among forty-six curves the note sumg was in thirtr-six instinces too lon: and in only te'n too high.

Experimental Inxestigation of the Influence of the Pharyngeal Constrictors on the Laryngeal Musculature.-Dreyfus (Nitritburm).- The experiments were designed to throw light on the quitestion of how to explain the characteristie larringeseopic picture observed in certain pharrugeal paralseses, such as bilhar and also post-riphtheriti. paralrsis. The deficient assure of the ghottis daring phomation is to be: ascribed, not to an anluctor paralysis of nerrous erigin, but to the paralssis of the phargmeral constrictors. As at result of the latter the muscles of phomation are leprived of the ponerful purchase which $i$. necessary for the production of a resonant voice, and which is silpolies: hy the concomitant contration of the larrngepharyneal musele, which is attacherd on either side to the thyroid and criend "artilagess, and, when it contracts, stearlies them. Dreyfus, experimenting on dows diviled. without injury to nerves, in some cases the mithle (II. hyo-pharyogens, and in others the inferior (II. thyro-crien-pharrngess) constrictor, an i whtaines on division of the midelle constrietor inarked interference witle swallowing, hut no interference with the voice, and, on the other hanit, oni division of the inferior constrietor, ne difficulty of swallowing, but considerable disturbance of the voice. The inferior enstricter is therefore, an ingertant larygeal muscle concermes with the voice. It.

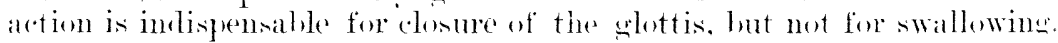

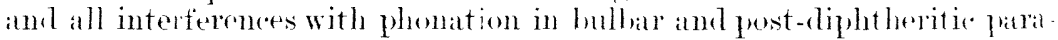
lysis atre to be attributed to its failure.

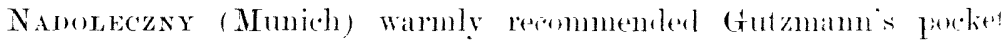
tuming fork, and resarded as useful atso his methor of electrification and vibuation of the larrix. Hont singers have only a relatively gerferet semst of pitels, while some very ummusical people have a perfecet sense of pitell He asked Dr. Dreyfus whether his experiments threw any light on the

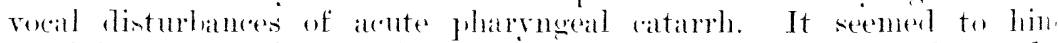
pessible that in this condition the functions of pharrngeal museles moln

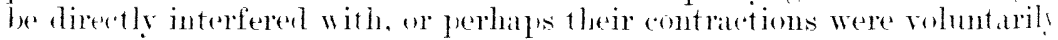
restricteti.

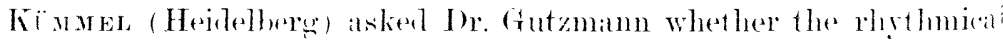
suression of electrical stimuli was in reality more effective tham the

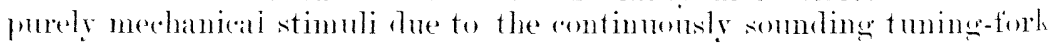
The latter often hat at disconcertinge effect in phodiastheniat.

bonstgraes (Brestaul) asked what was the effect, for example, in bulbar pratyosis, of artificial fixation of the larrux. If the opinion of 19r. Iregfus were correct, the voire should then berome normal.

Kimiran (Freiburg) regarded a tuning-fork apparatus, such as that of (tutzmamm. as of the greatest value in hysterical aphonia.

GOTZMANo, in reply, said that the conditions in phonasthenic patient were so extraordinarily diverse that one could never have too many way of testing them. Esjecially in hysterical aphonia the electrically driven tming-fork was more effective than vibration methols.

Sokolowsky, in replying, contimed the remarks of Narlolectny in reference to the sense of piteh of singers and musicians.

DRFycs, replying, said that the vocal disturbances in pharrngeal catarrh and acute diseases of the pharynx may certainly he attributed to 
whuntary restriction of movement. Artificial compression and fixation of fire larrix would prove nothing. They could not replace the innervation of the muscles; and, besiles, the inferior constrictor not only compressed 1:1e larynx, but also drew it upwards.

(To be rontinned.) Thos. Guthie (Trans.).

\section{FROCEEDINGS OF THE AMERICAN LARYNGO- LOGICAL, RHINOLOGICAL, AND OTOLOGICAL SOCIETY.}

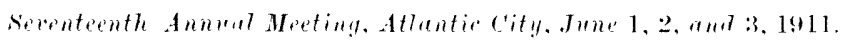

Repoit liy Dr. T. N. Inthran.

Thwath!n. J4ne 1, 1911.

(comtinued firmen rel. xxvi, p. (itil.)

The Method of Gixing Anæsthesia in Operations upon the Upper Respiratory Tract.-Dr. James Gwathmey (New Fork (ity) - The surgeon about to operate upon some portion of the upper mpiratory tract may select from such a variety of acrents am methods for inducing and maintaining anasthesia that the question of safety ind after-effects may be alsolutely eliminated. The agents for local aibisthesia are cocatine and its many allies, and morphine, ethyl chloride. amil sterile water. Morphine should precerle cocaine whenever possible, Indering the latter safer from inlitory reflexes, improving the anesthet ic. ant removing the psrchice element. 'The semeral anesthetics are nitrous

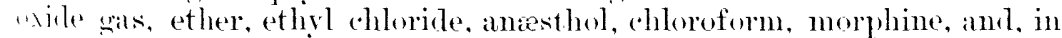
murerency cases, alcohol in the form of whisker or lorandr, combined with wimphine. The methods employed were enumerated at follows: Spinal Inalgesia, rectal anæsthesia, intra-venous anæsthesial, regional analgesia, mophine anasthesia, combined local and general anæsthesia, hypnotism 1. mental suggestion combines with some other method, the sequestralion method, intra-tracheal andesthesia, puhmonary anosthesia by the bisal or oral route, and electrical ancesthesia (one case in human being). The serentific hasis for the sucessful administration of all pulmonary anestheties comsists, in addition to the usual preparation of the patient, if (1) some preliminary medication; (2) anasthetic so arranged that any secquence or combinition can be quirkly made without interfering in the slightest with the operation; (3) all anxstheties heated to the tumperature of the blood; (4) combined with oxysen when indicated: (i) apparatus so constructed as to be able to administer the gases or ripurem under normal atmospheric pressure or positive pressure, and with moisture. Dr. Gwathmey emphasised the value of preliminary medicalion. Given thirty minutes before the operation it quiets a patient. as indicated by the normal heart-sounds; shortens the perion of induction, ithlishes unnecessary reflexes, and blunts others; diminishes the amount "if the anæsthetic one third to one half; renders holding and stropping imnecessary; diminishes the secretion of saliva to a negligible quantity, 